\title{
Colluvial legacies of millennial landscape change on individual hillsides, place-based investigation in the western Pyrenees Mountains
}

\author{
D. S. Leigh ${ }^{1}$, T. L. Gragson ${ }^{2}$, M. R. Coughlan ${ }^{2}$
}

${ }^{1}$ Department of Geography, The University of Georgia, 204 Geography-Geology Building, Athens, GA 30602, dleigh@uga.edu; ${ }^{2}$ Department of Anthropology, The University of Georgia, 204 Geography-Geology Building, Athens, GA 30602.

\section{Abstract}

We detect transition to agropastoral land use in a mountain landscape by radiocarbon dating physical signatures (sedimentation rates, charcoal concentrations, magnetic susceptibility) of conversion from native forest to pasture contained within colluvial stratigraphic sections. Focus is on two study sites located on toeslopes directly beneath zero-order hollows draining several hectares in the commune of Larrau (Pyrénées Atlantiques, France) along the international drainage divide of the western Pyrenees. Sample sites maximize likelihood of spatially and temporally uniform slopewash sedimentation. This constitutes a place-based approach to decipher the chronology of agropastoral activities within individual fields, which is applicable to other mountain ranges of the world. Stratigraphic columns were augured in contiguous $10 \mathrm{~cm}$ sample levels, which produced temporal resolution of decades to several centuries. We interpret relatively high concentrations of charcoal, rapid sedimentation, and magnetic susceptibility patterns as evidence of the intentional use of fire to transform forests into pastures. Results indicate that intentional burning and clearing probably were initiated by the Late Neolithic (ca. 5000-6000 cal. BP). However, intense burning, extensive forest clearance, and erosional degradation occurred later during the Bronze Age at one site, and during the Iron Age at the other site. This non-synchronous pattern of charcoal abundance and sedimentation rates is consistent with human agency of land clearance driving the chronology rather than paleoclimatic

drivers. Stratigraphic zones of rapid sedimentation at both sites constitute "legacy" sediment of great antiquity. Our results are consistent with similar shifts in fire regimes and vegetation assemblages derived from direct association with anthropogenic proxies (e.g. pastoral pollen taxa, fungal spores of sheep dung, and archaeological sites) elsewhere in the Pyrenees and other 
European mountains. Consequently, our method may provide a good indicator of human presence and land-use activities for mountainous areas where paleoenvironmental records from bogs, lakes, and archaeological sites are limited.

Keywords: colluvium, sediment, charcoal, radiocarbon, pastoral, Holocene

\section{Introduction}

We present multi-proxy physical stratigraphic evidence from deposits of colluvial slopewash that are indicative of mid-Holocene transformation of forest to pasture along the continental drainage divide between France and Spain in the western French Pyrenees Mountains. Regional pollen and charcoal records from lakes and peat bogs have established that agriculture, pastoral activities, and animal husbandry first appeared in the western Pyrenees circa 7500 cal. BP with notable expansion by 6000 cal. BP (Galop, 2006; Mazier et al., 2009; Rius, 2009; Rius et al. 2012; Galop et al., 2013; Pérez-Díaz et al., 2015). This evidence also indicates that human use of fire was instrumental for creating and maintaining pastures.

The prime-mover explanations were once favored for the expansion of domestication in Europe (Ammerman and Cavalli-Sforza 1984), but are yielding to evidence that the Neolithic transition was relatively abrupt and included both local adoption and independent domestication (Crubézy et al. 2006; Rowley-Conwy 2011; Zeder 2008). The initial insights leading to this shift in understanding the Neolithic transition were concentrated in highly evolved, low-gradient riverine environments (Berger 2011; Dotterweich 2008; Hoffmann et al. 2008), and rely on paleoenvironmental records derived from pollen, spores, and charcoal preserved in wetland and lake sediments at lower elevations. These windblown and fluvially transported microfossils represent watershed and regional scales of vegetation change having coarse spatial resolution. Interpreting the human capacity to transform earth processes over the Holocene by reference to a single activity (i.e. grazing) and using a fossil archive (i.e. pollen) can lead to simplistic and deterministic accounts that are no different than earlier prime-mover explanations (Cunill et al. 2013; Ejarque et al. 2011; Moe et al. 2007).

Agropastoralism is the primary means by which humans modified European mountain landscapes over the course of the Holocene (Bal et al. 2015; Cunill et al. 2013; Ejarque et al. 2011; Moe et al. 2007), but the geomorphic, topographic, climatic, and vegetative heterogeneity of these landscapes means that results obtained in one region may not be valid for interpreting 
mountain landscapes elsewhere (Ejarque et al. 2011; Mazier et al. 2009; Brun 2011). Accumulating evidence furthermore indicates that human land use over the Holocene in mountain landscapes was largely decoupled from climatic/temperature gradients (Cunill et al. 2013; Ejarque et al. 2011; Ejarque et al. 2010). Numerous studies now confirm that mountain landscapes are the result of climatic and anthropic pressures exerted and interrelated in a variable manner over the course of the Holocene (Bal et al. 2011; Ejarque et al. 2010; Pelachs et al. 2011; Vannière et al. 2001; Kaal et al. 2008).

While traditional paleoenvironmental archives convincingly portray how nascent Late Neolithic agropastoralism expands into extensive pastoral land use during the Bronze Age in mountainous terrain, they lack resolution on past human activities within individual fields. Consequently, little is known about the exact timing of past land-use changes at the spatial scale of individual hillsides, especially on high drainage divides. Here we test the idea that the Holocene chronology of landscape change from native forests to pastures is preserved in slopewash colluvium that accumulated on toeslopes of individual mountain hillsides. This placebased approach relies on changes in sedimentation rates, charcoal concentrations, and magnetic susceptibility to reconstruct activities of the first shepherds in the western Pyrenees.

\section{Material and Methods}

\subsection{Study area and sample sites}

We focus on two colluvial sites at 1350-1600 m elevation in the ethnically Basque commune of Larrau (12.7 km², Department of Pyrénées Atlantiques, France, Figs. 1 and 2). A single stratigraphic section was sampled from each site with auger borings of contiguous $10 \mathrm{~cm}$ sample intervals $(4.5 \mathrm{~m}$ deep hole at the Ihitsaga site and $1.8 \mathrm{~m}$ deep hole at Vallon de Mulhedoy). The southern boundary of the commune abuts the completely treeless international drainage-divide between France and Spain (Fig. 2). Bedrock consists of well stratified Mesozoic mudstone, shale, dolostone, and limestone that is steeply tilted and folded (Moores and Fairbridge, 1997) and capped by a thin mantle of noncalcareous silty to clayey yellowish-brown residuum. The residuum ranges from 0 to about $2 \mathrm{~m}$ thick, consisting of Alfisol type soils that tend to be more organically enriched in present-day pastures (Leigh et al., 2015).

The climate is humid oceanic (Atlantic) on the French side of the Pyrenees, with a mean long-term (AD 1956-2010) annual precipitation $~ 1700 \mathrm{~mm}$ and a mean annual temperature 
$\sim 13^{\circ} \mathrm{C}$ supporting mesophyllous vegetation. Native woodlands currently are dominated by beech (Fagus silvatica) that is often intermingled with fir (Abies pectinata) and oak (Quercus sp.). Most south facing slopes and both sides of the continental divide are covered with grasses and herbs, primarily bentgrass (Agrostis spp.), fescue (Festuca spp.), nard (Nardus stricta), and bluegrass (Poa spp) intermingled with various sedges (Family Cyperaceae) and legumes (e.g., Trifolium alpinum). These herbaceous communities are regularly maintained by intentional burning (Coughlan 2013) and would revert to woodlands without such human intervention, whereas the north facing slopes below $1300 \mathrm{~m}$ are largely forested (Fig. 2). No trees currently exist above $\sim 1700 \mathrm{~m}$, but the ecotone of the natural treeline would actually be around 2200-2300 $\mathrm{m}$ and ranged up to $\sim 2400 \mathrm{~m}$ during portions of the Holocene (Cunill et al., 2012). Native vegetation throughout the Holocene would have consisted almost entirely of woodlands if not for human alteration (Pérez-Díaz et al., 2015).

This research relies on two intensively studied colluvial depositional sites (Ihitsaga and Vallon de Mulhedoy; Figs. 1 and 2) that capture overland flow and slopewash sediment from entirely pastured hillslopes of zero-order drainages (i.e. no fluvial channels). These colluvial depositional sites comprise relatively flat toeslopes favoring sedimentary accumulation of slopewash, and lack mass-wasting deposits (landslide, slump, or debris flow deposits). Such flat toeslopes are relatively unique, as most backslopes drain directly into stream channels bypassing hillslope deposition. Nonetheless, the two colluvial sites studied capture sediment that is representative of the character of most of the sloping pastureland currently in use.

The sampled colluvial sections are small hollows that collect sediment from zero-order watersheds with drainage areas of 12 ha for Ihitsaga and and 4 ha for Vallon de Mulhedoy (referred to simply as "Mulhedoy" henceforth in the text, tables, and figures). The Ihitsaga site (1355-1590 m elevation) accumulates slopewash in a small trough or swale situated on a bedrock bench so that the flow from upslope converges somewhat into the trough. The Mulhedoy site accumulates slopewash on a bedrock bench that allows somewhat more divergent flow than at Ihitsaga. The Mulhedoy site was the object of a previous investigation (Leigh et al., 2015), but many new radiocarbon dates have been obtained and analytical techniques have been modified and improved since that study was conducted, comprising a new data set.

\subsection{Methodology}


A $7.6 \mathrm{~cm}$ diameter bucket auger was used to retrieve a contiguous column of $10 \mathrm{~cm}$ sample increments from each site. Samples were bagged, oven-dried at $105{ }^{\circ} \mathrm{C}$, and saved for laboratory analyses. Entire samples were gently disaggregated to pass an $8 \mathrm{~mm}$ mesh to avoid crushing large charcoal fragments, and subsamples were subjected to particle size, magnetic susceptibility, and charcoal analyses.

Particle size analysis determined the weight fractions of gravel $(>2000 \mu \mathrm{m})$, sand $(2000-$ $63 \mu \mathrm{m})$, silt $(63-2 \mu \mathrm{m})$, and clay $(<2 \mu \mathrm{m})$. Gravel is reported as the percent of the whole ovendried sample. Sand, silt, and clay are reported as weight percentages of the $<2 \mathrm{~mm}$ mineral soil following destruction of organic matter with hydrogen peroxide, wet sieving the sand through a $63 \mu \mathrm{m}$ mesh, and then obtaining the silt and clay percentages by the hydrometer method of Gee and Bauder (1986).

Subsamples crushed to pass a $2 \mathrm{~mm}$ mesh were measured for their low-frequency $(0.46$ $\mathrm{kHz}$ ) mass-specific magnetic susceptibility with $10.0 \mathrm{~g}$ samples contained within $20 \mathrm{ml}$ plastic vials. Each sample was measured on two separate occasions with a Bartington ${ }^{\mathrm{TM}} \mathrm{MS} 3$ magnetic susceptibility meter with the reported value being the average. Twenty-five replicates of one sample indicate a standard deviation of $0.001057 \times 10^{-6} \mathrm{~m}^{3} \mathrm{~kg}^{-1}$ or 0.70 percent of the mean sample value of $0.15044810^{-6} \mathrm{~m}^{3} \mathrm{~kg}^{-1}$.

In addition to the colluvial profiles, we measured a set of surface soil samples that include four ancient pastures maintained by regular burning paired with directly adjacent tracts of old forests with very low probability of intentional burning (Coughlan, 2014). Five pairs of samples were collected from each respective pasture and forest site. This set of paired pasture/forest samples was previously documented for bulk density measurements (Leigh et al. 2015). Magnetic susceptibility results from these 20 pairs clearly demonstrate that the samples from regularly burned pastures register very significantly higher magnetic susceptibility values than the unburnt forests (Fig. 3). Based on this result, in addition to literature indicating enhancement of soil magnetic susceptibility from fires (e.g. Dearing, 1994; Gedye et al., 2000; Blake et al., 2006; Oldfield and Crowther, 2007), we hypothesize that fire used in the initial conversion of forests to pastures (and subsequently to maintain pastures) would be reflected by enhanced magnetic susceptibility of burnt colluvium in the stratigraphic profiles.

Small fragments of charcoal were removed from the auger cuttings and radiocarbon $\left({ }^{14} \mathrm{C}\right)$ dated by the accelerator mass spectrometry (AMS) method at the University of Georgia's Center 
for Applied Isotope Studies. The charcoal was cleaned and leached of possible carbonates with an acid-alkali-acid pretreatment prior to ${ }^{14} \mathrm{C}$ dating. Bulk sediment material was also dated following ultrasonic dispersion and sieving through $125 \mu \mathrm{m}$ mesh and cleaning with $1 \mathrm{~N} \mathrm{HCl}$ to remove possible carbonates. Calendar year calibrations were calculated using the Classic Age Model (CLAM) program (Blaauw, 2010) based on the IntCal13 calibration curve (Reimer et al., 2013) and the ${ }^{13} \mathrm{C}$-corrected ${ }^{14} \mathrm{C}$ ages. The calendar years before present (cal. BP) reference A.D. 1950 as "present". Sedimentation rates were calculated by linear and smoothed spline interpolations with the program CLAM (Blaauw, 2010), which considered the probability distributions of the separate radiocarbon dates in 10000 iterations to produce the most probable match to interpolate between the two samples.

We acknowledge that charcoal may be detritus thus possibly producing erroneous ages for the actual time of sedimentation. However, we are careful to selectively date the largest angular fragments of charcoal that exhibit minimal traits of abrasion and rounding, and our radiocarbon chronology is bolstered by several bulk sediment dates that are compatible with dates from charcoal (Tables 1 and 2).

Subsamples of $10-15 \mathrm{~g}$ of the $<8 \mathrm{~mm}$ fraction were gently dispersed in a $100 \mathrm{~g} / \mathrm{L}$ solution of sodium hexametasphosphate for at least 72 hours and then wet-sieved to pass a 125 $\mu \mathrm{m}$ mesh. Charcoal $>125 \mu \mathrm{m}$ derives from local fires as opposed to windblown charcoal from distant sources (Clarke and Royall, 1995), and Higuera et al. (2005) demonstrate that >125 $\mu \mathrm{m}$ charcoal in colluvium from small hollows produces a reliable record of past fires. The $>125 \mu \mathrm{m}$ residue (sand + organic matter) was bathed in a 5 percent solution of hydrogen peroxide (to destroy/bleach non-charcoal organics) and then oven-dried at $105{ }^{\circ} \mathrm{C}$. The dry $>125 \mu \mathrm{m}$ residue was gently salted into a plastic vial containing liquid sodium polytungstate with a density of 1.75 $\mathrm{g} \mathrm{cm}^{-3}$, and the floating fraction containing charcoal was removed by freezing the entire liquid and then rinsing the floated surface material on to Whatman \#1 filter paper using warm water on to a vacuum filtration funnel and flask. The residue on the filter paper was photographed at 10 $\mu \mathrm{m}$ pixel resolution, and the area of uniquely black charcoal fragments were quantified with the image analysis program Sigma Scan Pro 5. The area of charcoal is normalized to a cubic centimeter based on an average dry bulk density of $1.5 \mathrm{~g} \mathrm{~cm}^{-3}$.

\section{Results}




\subsection{Stratigraphy}

The two colluvial sections have similar stratigraphy given that both consist of very homogenous, massive, light brown (10YR 5/4) silt loam to silty clay loam in the upper stratigraphic unit, which overlies a slightly darker and somewhat coarser lower unit (Figs. 4 and 5). The lower unit at Ihitsaga contains slightly more gravel and sand than the upper unit (Fig. 4), and the lower unit at Mulhedoy is slightly siltier than the upper unit (Fig. 5). There is no indication of any significant hiatus in sedimentation or unconformity within the upper unit at either site, and the boundary between the upper and lower units is conformable at both sites. The upper and lower units at Ihitsaga are much thicker than those at Mulhedoy (upper unit thicknesses of $2.90 \mathrm{~m}$ vs. $1.55 \mathrm{~m}$, and lower unit thicknesses of 1.60 vs. $0.25 \mathrm{~m}$, respectively). Radiocarbon dates (Tables 1 and 2) indicate the upper units in both sections fall entirely within the Holocene epoch, whereas the lower units extend down into the latest Pleistocene. The Ihitsaga section is coarser textured and contains considerably more gravel than the Mulhedoy section, indicating slightly higher energy conditions of slopewash. A few sand and gravel lenses were present at Ihitsaga, but not at Mulhedoy. The auger refused on coarse gravel and cobbles or bedrock in both sections (at $4.5 \mathrm{~m}$ at Ihitsaga and $1.8 \mathrm{~m}$ at Mulhedoy).

Only slight pedogenic alteration is apparent at both sites, expressed by weak cambic B horizons $(\mathrm{Bw})$ in the surface soils that only extend down to $40-50 \mathrm{~cm}$ below ground surface. These weak $\mathrm{Bw}$ horizons are characterized by slightly redder colors and moderate subangular blocky ped structure.

\subsection{Chronology and sedimentation rates}

A smoothed spline interpolation was applied to both sites to accommodate a distinct nonlinear depth-age pattern characterized by an apparent zone of very rapid sedimentation in the midst of the upper unit at both sites (Tables 1 and 2; Figs. 6 and 7). Sedimentation rates were very slow during the Neolithic and earlier, rapid during the Bronze Age to Iron Age and relatively slow again during the last few millennia. Sediment compaction does not appear to relate this temporal variation in sedimentation rates, because the sediment bulk density is

relatively constant (at $1.5 \mathrm{~g} \mathrm{~cm}^{-1}$ ) beneath the organically enriched zone of the top $30 \mathrm{~cm}$ of the profiles. The zone of very rapid sedimentation occurs around 2000-3000 cal. BP at Ihitsaga, and around 3500-4500 cal. BP at Mulhedoy (Fig. 7). Especially within the zones of rapid 
sedimentation it is possible that the shallower radiocarbon samples could represent age inversions due to detrital transport of charcoal older than the time of sedimentation. Nonetheless, CLAM was still able to resolve a linear interpolation model of progressively decreasing ages through all of the points at both sites (Fig. 6), given the 95\% confidence intervals of the radiocarbon calibrations (Tables 1 and 2), so age inversions do not necessarily occur. We contend that a smoothed spline interpolation produces the most realistic and parsimonious depth-age model, because it is unlikely that the selected radiocarbon samples fortuitously capture the exact points of changes in sedimentation rates. Also, the smoothed spline interpolation accommodates the realistic possibility of detrital age inversions as well as slight sample displacement by bioturbation. Although it is impossible to know exactly which depth-age model is most truthful, we found (in comparison to the wide spectrum of other models available in the CLAM program) that the smoothed spline models best satisfied the five items recommended by Blaauw and Heegard (2012, pp. 407-408) for choosing the most appropriate model. Thus, the smoothed spline models are used for subsequent analysis and discussion.

At Ihitsaga sedimentation rates steadily decrease from 0.36 to $0.20 \mathrm{~mm} \mathrm{y}^{-1}$ during 13200 cal. BP to $4000 \mathrm{cal}$. BP, and shortly after $4000 \mathrm{cal}$. BP they begin to increase, achieving $0.40 \mathrm{~mm}$ $\mathrm{y}^{-1}$ by $3000 \mathrm{cal}$. BP, and peaking at $>1 \mathrm{~mm} \mathrm{y}^{-1}$ (and up to $7 \mathrm{~mm} \mathrm{y}^{-1}$ ) at 2600-2300 cal. BP. After $2300 \mathrm{cal}$. BP the sedimentation rates at Ihitsaga steadily decrease achieving 0.50 to $0.25 \mathrm{~mm} \mathrm{y}^{-1}$ during the last 2000 years.

Slower sedimentation rates overall are observed at Mulhedoy, with the slowest rates of 0.04 to $0.07 \mathrm{~mm} \mathrm{y}^{-1}$ during the terminal Pleistocene and early Holocene. Similar to Ihitsaga, a late Holocene increase in sedimentation rates occurs at Mulhedoy, although at about 1500 years earlier. Rates double from $0.07 \mathrm{~mm} \mathrm{y}^{-1}$ to $0.14 \mathrm{~mm} \mathrm{y}^{-1}$ between 5400 and $4400 \mathrm{cal}$. BP, peak at > $1 \mathrm{~mm} \mathrm{y}^{-1}$ (and up to $7 \mathrm{~mm} \mathrm{y}^{-1}$ ) at 3900-3800 cal. BP, then drop below $0.50 \mathrm{~mm} \mathrm{y}^{-1}$ at $3700 \mathrm{cal}$. BP.

\section{3. $>125 \mu \mathrm{m}$ Charcoal}

Tabulation of $>125$ micron charcoal at both Ihitsaga and Mulhedoy reveals only trace amounts of charcoal prior to 6000-7000 cal. BP and relatively abundant charcoal subsequently (Figs. 4-5, and Fig. 8). This result strongly suggests that fire was rare on the local hillsides 
during the latest Pleistocene and early Holocene, becoming much more common after 6000 cal. BP.

At Ihitsaga, charcoal densities are consistently less than $0.04 \mathrm{~mm}^{2} \mathrm{~cm}^{-3}$ from $450-290 \mathrm{~cm}$ throughout the lower unit, increase by an order of magnitude to $0.42 \mathrm{~mm}^{2} \mathrm{~cm}^{-3}$ between 290 and $230 \mathrm{~cm}$, then initiate a pronounced increase at $230 \mathrm{~cm}$ jumping from 0.42 to $1.24 \mathrm{~mm}^{2} \mathrm{~cm}^{-3}$ in the $30 \mathrm{~cm}$ interval from $230 \mathrm{~cm}$ to $200 \mathrm{~cm}$ (Fig. 4). The distinct increase starting at $230 \mathrm{~cm}$ is modeled at $5558 \mathrm{cal}$. BP according to the smoothed spline curve (95\% confidence interval of 5374-5692 cal. BP). Thereafter, charcoal concentrations remain above $0.1 \mathrm{~mm}^{2} \mathrm{~cm}^{-3}$ and range widely up to $5.4 \mathrm{~mm}^{2} \mathrm{~cm}^{-3}$ with four apparent peaks (Fig. 4).

Approximately one order-of-magnitude less charcoal is present at Mulhedoy than at Ihitsaga (Figs. 4 and 5), probably because of its much smaller drainage area. The pattern is nonetheless similar to the one at Ihitsaga. Only trace amounts of $<0.01 \mathrm{~mm}^{2} \mathrm{~cm}^{-3}$ of charcoal exist beneath $150 \mathrm{~cm}$ along with zero values in a few samples. Densities creep up from 0.07 to $0.30 \mathrm{~mm}^{2} \mathrm{~cm}^{-3}$ within the $150-120 \mathrm{~cm}$ interval, attaining a value of $0.30 \mathrm{~mm}^{2} \mathrm{~cm}^{-3}$ in the $110-120$ $\mathrm{cm}$ sample representing a doubling from the sample below. This pronounced increase at $120 \mathrm{~cm}$ is modeled at $5793 \mathrm{cal}$. BP according to the smoothed spline curve (95\% confidence interval of 4709-6853 cal. BP). Thereafter, charcoal densities remain above $0.30 \mathrm{~mm}^{2} \mathrm{~cm}^{-3}$ and range widely up to $1.42 \mathrm{~mm}^{2} \mathrm{~cm}^{-3}$ with two pronounced peaks.

Charcoal accumulation rates (CHAR), calculated as the product of charcoal densities $\left(\mathrm{mm}^{2} \mathrm{~cm}^{-3}\right)$ and sedimentation rates $\left(\mathrm{cm} \mathrm{y}^{-1}\right)$ (Fig. 8), essentially reveal patterns that reflect the non-synchronous time periods of rapid sedimentation between the two sites. This nonsynchronous pattern is consistent with a human-induced stratigraphic signature, rather than a climate-induced signature. These data indicate that major activity of land clearance using fire occurred at Mulhedoy around $4000 \mathrm{cal}$. BP, approximately 1500 years earlier than at Ihitsaga.

Aside from the maximum charcoal influx peaks during the Bronze Age at Mulhedoy and Iron Age at Ihitsaga, CHAR data from both stratigraphic sections reveal a pronounced and sustained uptick in fire activity at 5000-6000 cal. BP probably attributable to human ignitions. Very low CHAR values prior to 6000-7000 cal. BP indicate that fire occurred during the late Pleistocene and early Holocene, and establish background levels of CHAR that may be attributable to non-anthropic ignitions. At Ihitsaga, these background CHAR values are $<0.0012$ $\mathrm{mm} \mathrm{cm} \mathrm{y}^{-1}$ and at Mulhedoy $<0.0004 \mathrm{~mm} \mathrm{~cm}^{2} \mathrm{y}^{-1}$. However, approximately an order-of- 
magnitude increase in CHAR occurs between 9000 to 6000 cal. BP at both sites, and it remains uncertain how much of this can be attributed to human versus natural ignitions.

\subsection{Magnetic Susceptibility}

Magnetic susceptibility indicates that burnt soil becomes apparent in the stratigraphic record at 220-230 cm in the Ihitsaga section and at 110-120 cm in the Mulhedoy section (Figs. 4 and 5), both within exactly the same sample interval as the uptick in charcoal densities mentioned above at 5000-6000 cal. BP. Above that point in both stratigraphic sections the magnetic susceptibility values are consistently above $0.125 \times 10^{-6} \mathrm{~m}^{3} \mathrm{~kg}^{-1}$ (the combined average value for data from both sites), whereas below that point all magnetic susceptibility values are

below $0.125 \times 10^{-6} \mathrm{~m}^{3} \mathrm{~kg}^{-1}$ (Figs. 4 and 5), which appears to be a reasonable background threshold value. Although magnetic enhancement by pedogenesis cannot be ruled out, neither stratigraphic section shows a pattern that indicates pedogenesis as the main driver of the magnetic susceptibility signal. In fact, Ihitsaga completely lacks a magnetic susceptibility bulge in the Bw horizon where it would be most likely to occur. Instead, the peaks and valleys in the magnetic susceptibility roughly match the charcoal record (Figs. 4 and 5) if some lag time is allowed for transport of the fire-induced magnetic signal downslope to the depositional site. An exception is the upper peak charcoal concentrations at $40-60 \mathrm{~cm}$ at Ihitsaga (Fig. 4) where the charcoal peak does not have a possible correlative magnetic susceptibility peak.

\section{Discussion and Conclusions}

The Ihitsaga and Mulhedoy records indicate that fully developed land clearance and ensuing erosion occurred during very different time spans (Bronze Age versus Iron Age) at these sites. This non-synchronous behavior supports human agency of landscape change, rather than paleoclimate drivers. This also suggests that the summits of the western Pyrenees may have appeared as fragmented or patchy landscapes of forests with gaps of small grasslands and shrubs from the Late Neolithic until the Iron Age. The initial increase in charcoal at 5000-6000 cal. BP (and perhaps earlier), and its implied burning activities, may only have occurred in and around small flat to gently sloping areas near the base of each watershed. In contrast, the pronounced increases in charcoal and sedimentation rates much later in time relate to more complete clearance of the entire watershed that stimulated severe erosion possibly for hundreds of years. 
This would explain influx of charcoal in the Late Neolithic without increases in sedimentation rates. We favor the idea that landscape conversion from the Neolithic to the Bronze Age was not rapid and it may not have been unidirectional. Indeed, some intentionally cleared areas may have reverted back to forest prior to the more permanent conversion to grassland. In general, we suggest the Neolithic to Bronze Age pattern of land use was extensive and patchy, rather than intensive and widespread.

Our data identify Bronze Age and Iron Age "legacy sediment", which James (2013) defines as "episodically produced anthropogenic sediment", regardless of age. The zones of maximum sedimentation rates during the Bronze Age at Mulhedoy (up to $7 \mathrm{~mm} \mathrm{y}^{-1}$ ) and during the Iron Age at Ihitsaga (also up to $7 \mathrm{~mm} \mathrm{y}^{-1}$ ) are well outside of the forested background range, as indicated by the slow rates of 0.04 to $0.4 \mathrm{~mm} \mathrm{y}^{-1}$ during the early Holocene. In addition, Leigh et al. (2015) surmised rates of $>1 \mathrm{~mm} \mathrm{y}^{-1}$ to be outside of the range for humid-temperateforested mountains. Thus, it is highly likely that both Ihitsaga and Mulhedoy were both "degraded" with highly eroded soils during their phase of maximum forest clearance, yet both of these sites have since recovered to exhibit relatively slow sedimentation rates $<1 \mathrm{~mm} \mathrm{y}^{-1}$ from completely pastured watersheds. Although both sites exhibit modern sedimentation rates that are slightly above the early Holocene background values, they are well within the "forested" realm of $<1 \mathrm{~mm} \mathrm{y}^{-1}$. This is significant because it demonstrates that hillslopes degraded by erosion can recover with time, given appropriate soil conservation and sustainability practices. Indeed, Leigh et al. (2015) found that many present-day pastured soils in Larrau had thicker A horizons, more organic matter, and lower bulk density than their forested counterparts, so that the stereotypical model of landscape degradation from grazed lands is not always the outcome.

Our results agree with numerous studies from the Pyrenees and other mountains throughout Europe that indicate emergent human-induced deforestation reliant on fire during the Middle- to Late-Neolithic, followed by fully developed agropastoral landscape conversion with fire during the Bronze and Iron Ages (Olsson et al. 2000; Valsecchi et al. 2010; Cunill et al. 2012; Rius et al., 2012; Galop et al. 2013) . However, our place-based results uniquely target the hectare-scale of individual hillsides and associated long-term histories of burning and erosion. Our data affirm the colluvial sedimentary record is capable of detecting increasing prevalence of fire from the Neolithic onward as well as major changes in erosion and sedimentation rates. A drawback is that the temporal resolution can be relatively coarse, due to slow sedimentation rates 
and problems associated with reworking of dateable material from detrital transport and bioturbation.

Similar studies of the Holocene colluvial record of human-induced landscape change are increasingly common in the mountains of Europe (Kaal et al., 2008, Favilli et al., 2010; Roepke et al., 2011; Dotterweich et al., 2013; Roepke and Krause, 2013) and elsewhere (Okunaka et al., 2011). Such place-based colluvial investigations are particularly useful for reconstructing land use activities in localities where paleoenvironmental records from bogs and lakes may be unavailable, distant, or in completely different watersheds. Indeed, Galop et al. (2013, p. 23) note that the "...earliest agro-pastoral communities may have operated at a scale too small, or below a disturbance threshold, to be detectable by pollen analysis and thus their activities remain a 'blind spot' in our history". Our colluvial place-based approach promises to help fill this gap.

\section{Acknowledgements}

We thank the leaders and residents of the commune of Larrau for allowing and facilitating our research. Dr. Pascal Palu assisted with logistical arrangements for field work. The recovery of auger samples during field work was greatly assisted by the efforts of Zach Sanders. Maria Jose Oliveira provided essential laboratory assistance, and Dr. Jennifer Birch facilitated use of the magnetic susceptibility device. Partial support was provided by the National Geographic Society (grant \#9573-14), Coweeta Long Term Ecological Research program funded by the National Science Foundation (award DEB-0823293) and by a Partner University Fund award to the University of Georgia and the Universite de Pau.

\section{References}

Ammerman A.J., Cavalli-Sforza L.L., 1984. The Neolithic Transition and the Genetics of Populations in Europe. Princeton, NJ: Princeton University Press.

Bal M.-C., Allée P., Liard M., 2015. The origins of a Nardus stricta grassland through soil charcoal analyses: Reconstructing the history of a mountain cultural landscape (Mont Lozère, France) since the Neolithic. Quaternary International 366, 3-14.

Bal M.-C., Pelachs A., Pérez-Obiol R., Julià R.n., Cunill R., 2011. Fire history and human activities during the last 3300 cal y BP in Spain's Central Pyrenees: The case of the Estany de Burg. Palaeogeography, Palaeoclimatology, Palaeoecology 300, 179-190. 
Berger J.-F., 2011. Hydrological and post-depositional impacts on the distribution of Holocene archaeological sites: The case of the Holocene middle Rhône River basin, France. Geomorphology 129, 167-182.

Blake, W.H., Wallbrink, P.J., Doerr, S.H., Shakesby, R.A., Humphreys, G.S. 2006. Magnetic enhancement in wildfire-affected soil and its potential for sediment-source ascription. Earth Surface Processes and Landforms 31, 249-264.

Blaauw, M., 2010. Methods and code for 'classical' age-modelling of radiocarbon sequences. Quaternary Geochronology 5, 512.

Blaauw, M., Heegaard, E, 2012. Estimation of age-depth relationships. Chapter 12 In: H.J.B. Birks, A.F. Lotter, S. Juggins, J.P. Smol (Eds.), Tracking Environmental Change Using Lake Sediments: Data Handling and Numerical Techniques, Developments in Paleoenvironmental Research 5. Springer, New York, pp. 379-413.

Brun C., 2011. Anthropogenic indicators in pollen diagrams in eastern France: A critical review. Vegetation History \& Archaeobotany, 20, 135-142.

Clark, J.S., Royall, P.D., 1995. Particle-size evidence for source areas of charcoal accumulation in late Holocene sediments of eastern North American lakes. Quaternary Research 43, 8089.

Coughlan, M. R., 2013. Errakina: pastoral fire use and landscape memory in the Basque region of the French Western Pyrenees. Journal of Ethnobiology 33, 86-104.

Coughlan, M. R., 2014. Farmers, flames and forests: historical ecology of pastoral fire use and landscape change in the French western Pyrenees 1830-2011. Forest Ecology and Management 312, 55-66.

Crubézy E., Ludes B., Guilaine J., 2006. Génétique et peuplements néolithiques, in Populations Néolithiques et Environnements, edited by J. Guilaine. Paris: Editions Errance, pp. 43-62.

Cunill, R., Soriano, J.M., Bal, M.C., Pelachs, A., Perez-Obiol, R., 2012. Holocene treeline changes on the south slope of the Pyrenees: a pedoanthracological analysis. Vegetation History and Archaeobotany 21, 373-384.

Cunill R., Soriano J.M., Bal M.C., Pèlachs A., Rodriguez J.M., Pérez-Obiol R., 2013. Holocene high-altitude vegetation dynamics in the Pyrenees: A pedoanthracology contribution to an interdisciplinary approach. Quaternary International 289, 60-70. 
Dearing, J., 1994. Environmental Magnetic Susceptibility: Using the Bartington MS2 System. Oxford, UK: Bartington Instruments Inc.

Dotterweich M., 2008. The history of soil erosion and fluvial deposits in small catchments of central Europe: Deciphering the long-term interaction between humans and the environment -- A review. Geomorphology 101, 192-208.

Dotterweich, M., 2013. The history of human-induced soil erosion: Geomorphic legacies, early descriptions and research, and the development of soil conservation-A global synopsis. Geomorphology 201, 1-34.

Ejarque A., Miras Y., Riera S., Palet J.M., Orengo H.A., 2010. Testing micro-regional variability in the Holocene shaping of high mountain cultural landscapes: a palaeoenvironmental casestudy in the eastern Pyrenees. Journal of Archaeological Science 37, 1468-1479.

Ejarque A., Miras Y., Riera S., 2011. Pollen and non-pollen palynomorph indicators of vegetation and highland grazing activities obtained from modern surface and dung datasets in the eastern Pyrenees. Review of Palaeobotany and Palynology, 167, 123-139.

Favilli, F., Cherubini, P., Collenberg, M., Egli, M., Sartori, G., Schoch, W., Haeberli, W., 2010. Charcoal fragments of Alpine soils as an indicator of landscape evolution during the Holocene in Val di Sole (Trentino, Italy). The Holocene 20, 67-79.

Galop, D., 2006. La conquête de lamontagne Pyrénéenne au Néolithique. Chronologie, rythmes et transformations des paysages à partir des données polliniques. In: Guilaine, J. (Ed.), Populations néolithiques et environnement. Editions Errance, pp. 279-295.

Galop, D., Rius, D., Cugny, C., Mazier, F., 2013. A history of long-term human-environment interactions in the French Pyrenees inferred from the pollen data. In: Lozny, L.R. (Ed.), Continuity and Change in Cultural Adaptation to Mountain Environments: from Prehistory to Contemporary Threats. Springer, New York, pp. 19-30.

Gedye, S. J., Jones, R.T., Tinner, W, Ammann, Oldfield, F., 2000. The use of mineral magnetism in the reconstruction of fire history: a case study from Lago di Origlio, Swiss Alps. Palaeogeography, Palaeoclimatology, Palaeoecology 164, 101-110.

Gee, G.W. and Bauder, J.W., 1986. Particle Size Analysis. In Klute, A. (ed.): Methods of Soil Analysis, Part 1. Physical and Mineralogical Methods. Agronomy Monograph No. 9 (2nd edition): 383-411: Madison, WI: American Society of Agronomy and The Soil Science Society of America. 
Higuera, P.E., Sprugel, D.G., Brubaker, L.B., 2005. Reconstructing fire regimes with charcoal from small-hollow sediments; a calibration with tree-ring records of fire. Holocene 15, 238251.

Hoffmann T., Lang A., Dikau R., 2008. Holocene river activity: Analyzing 14 C-dated fluvial and colluvial sediments from Germany. Quaternary Science Reviews, 27, 2031-2040.

James, L.A., 2013. Legacy sediment: Definitions and processes of episodically produced anthropogenic sediment. Anthropocene 2, 16.

Kaal J., Martínez-Cortizas A., Buurman P., Boado F.C., 2008. 8000 y of black carbon accumulation in a colluvial soil from NW Spain. Quaternary Research 69, 56-61.

Kaal, J., Cortizas, A.M., Eckmeier, E., Casais, M.C., Estévez, M.S., Boado, F.C. 2008. Holocene fire history of black colluvial soils revealed by pyrolysis-GC/MS: a case study from Campo Lameiro (NW Spain). Journal Of Archaeological Science 35, 2133-2143.

Leigh, D.S., Gragson, T.L., Coughlan, M.R., 2015. Chronology and pedogenic effects of mid- to late-Holocene conversion of forests to pastures in the French western Pyrenees. Zeitschrift für Geomorphologie, in press.

Mazier, F., Galop, D., Gaillard, M.-J., Rendu, C., Cugny, C., Legaz, A., et al. (2009). Multidisciplinary approach to reconstruct pastoral activities. An example from the Pyrenean Mountains (Pays Basque). Holocene, 19, 171-178.

Moe D., Fedele F., Engan A., Kvamme M., 2007. Vegetational changes and human presence in the low-alpine and subalpine zone in Val Febbraro, upper Valle di Spluga (Italian central Alps), from the Neolithic to the Roman period. Vegetation History \& Archaeobotany, 16, 431-451.

Moores, E.M., Fairbridge, R.W., 1997. Encyclopedia of European and Asian regional geology Encyclopedia of Earth sciences series. Chapman \& Hall : London, United Kingdom.

Okunaka, R., Kawano, T., Inoue, J., 2011. Holocene history of intentional fires and grassland development on the Soni Plateau, Central Japan, reconstructed from phytolith and macroscopic charcoal records within cumulative soils, combined with palaeoenvironmental data from mire sediments. The Holocene 22, 793-800.

Oldfield, F., Crowther, J., 2007. Establishing fire incidence in temperate soils using magnetic measurements. Palaeogeography, Palaeoclimatology, Palaeoecology 249, 362-369. 
Olsson E.G.A., Austrheim G., Grenne S.N., 2000. Landscape change patterns in mountains, land use and environmental diversity, mid-Norway 1960-1993. Landscape Ecology 15, 155-170.

Pelachs A., Julià R.n., Pérez-Obiol R., Soriano J.M., Bal M.-C., Cunill R., Catalan J., 2011. Potential influence of bond events on mid-Holocene climate and vegetation in southern Pyrenees as assessed from Burg lake LOI and pollen records. The Holocene, 21 95-104.

Perez-Díaz, S., Lopez-Saez, J.A., Galop, D. 2015. Vegetation dynamics and human activity in the Western Pyrenean Region during the Holocene, Quaternary International, 364, 65-77.

Reimer, P.J., Bard, E., Bayliss, A., Beck, J.W., Blackwell, P.G., Ramsey, C.B., Buck, C.E., Hai, C., Edwards, R.L., Friedrich, M., Grootes, P.M., Guilderson, T.P., Haflidason, H., Hajdas, I., Hatté, C., Heaton, T.J., Hoffmann, D.L., Hogg, A.G., Hughen, K.A., Kaiser, K.F., 2013. INTCAL13 and MARINE13 Radiocarbon Age Calibration Curves 0-50,000 years cal BP. Radiocarbon 55, 1869-1887.

Rius, D., 2009. Fire frequency and landscape management in the northwestern Pyrenean piedmont, France, since the early Neolithic (8000 cal. BP). Holocene 19, 847.

Rius, D., Vanniere, B., Galop, D., 2012. Holocene history of fire, vegetation and land use from the central Pyrenees (France). Quaternary Research 77, 54-64.

Röpke, A., Stobbe, A., Oeggl, K., Kalis, A.J., Tinner, W., 2011. Late-Holocene land use history and environmental changes at the high altitudes of St. Antönien (Switzerland, Northern Alps) -combined evidence from pollen, soil and tree ring analyses. The Holocene 21, 485498.

Roepke, A., Krause, R., 2013. High montane-subalpine soils in the Montafon Valley (Austria, northern Alps) and their link to land-use, fire and settlement history. Quaternary International 308-308, 178-189.

Rowley-Conwy P., 2011. Westward Ho! Current Anthropology, S431-S451.

Valsecchi V., Carraro G., Conedera M., Tinner W., 2010. Late-Holocene vegetation and landuse dynamics in the southern Alps (Switzerland) as a basis for nature protection and forest management, The Holocene 20, 483-495.

Vannière B., Galop D., Rendu C., Davasse B., 2001. Feu et pratiques agro-pastorales dans les Pyrénées-Orientales: le cas de la montagne d'Enveitg (Cerdagne, Pyrénées-Orientales, France), Sud-Ouest Européen: Toulouse: Presses Universitaires du Mirail - CNRS, pp. 2942. 
Zeder M.A., 2008. Domestication and early agriculture in the Mediterranean Basin: Origins, diffusion, and impact. Proceedings of the National Academy of Sciences, 105, 1159711604.

\section{List of Figures:}

Fig. 1. Map showing the location of the study area in southwestern France and locations of the two colluvial stratigraphic sections, Ihitsaga (Lat. $42.965920^{\circ}$, Long. $-0.889184^{\circ}$, elev. 1355 masl) and Vallon de Mulhedoy (Lat. $42.962880^{\circ}$, Long. $-0.950112^{\circ}$, elev. 1505 masl).

Fig. 2. Oblique aerial image of the zero order watersheds above the Ihitsaga and Mulhedoy colluvial sites. The summit above Ihitsaga and Mulhedoy is the international drainage divide between France and Spain, looking to the southwest. The image is from Google Earth, Inc.

Fig. 3. Low frequency magnetic susceptibility results from 20 pairs of side-by-side forest and burnt pasture sites drawn from four separate hillslope sites in the commune of Larrau, France. Each matched pair of forest versus pasture samples has the same X-axis position on the graph and represents the same position on the hillslope. Site localities are specified by Leigh et al. (2015).

Fig. 4. Stratigraphy and physical characteristics of the Ihitsaga colluvial stratigraphic section.

Fig. 5. Stratigraphy and physical characteristics of the Mulhedoy colluvial stratigraphic section.

Fig. 6. Depth-age models for the Ihitsaga and Mulhedoy stratigraphic sections. The thin straight line segments represent linear models through dated samples, and the thicker solid and dashed lines represent the smoothed spline curves. Control points corresponding to the calibrated ages of the actual samples are provided with circles for the Ihitsaga section and stars for the Mulhedoy section.

Fig. 7. Sedimentation rates for the Ihitsaga and Mulhedoy stratigraphic sections based on the smoothed spline depth-age models. Control points corresponding to the interpolated ages 
corresponding to actual samples are provided with circles for the Ihitsaga section and stars for the Mulhedoy section.

Fig. 8. Charcoal accumulation rate (CHAR) plots for the Ihitsaga and Mulhedoy stratigraphic sections.

Table 1. Radiocarbon dates from the Ihitsaga colluvial stratigraphic section.

\begin{tabular}{|c|c|c|c|c|c|c|c|c|c|}
\hline $\begin{array}{c}\text { Depth } \\
(\mathrm{cm})\end{array}$ & $\begin{array}{l}\text { Plot } \\
\text { Pt. } \\
\text { (cm) }\end{array}$ & Material & $\begin{array}{c}\text { UGA } \\
\text { Lab \# }\end{array}$ & $\delta^{13} \mathrm{C} \%$ & ${ }^{14} \mathrm{C} B P$ & $\begin{array}{c}+/-1 \\
\text { Sigma }\end{array}$ & $\begin{array}{c}\text { 95\% } \\
\text { C.I. } \\
\text { Min. } \\
\text { Cal. BP }\end{array}$ & $\begin{array}{c}95 \% \\
\text { C.I. } \\
\text { Max. } \\
\text { Cal. } \\
\text { BP } \\
\end{array}$ & $\begin{array}{c}\text { Prob. } \\
\% \\
\end{array}$ \\
\hline 0 & 0 & surface & n.a. & n.a. & -63 & 1 & -65 & -62 & 95 \\
\hline \multirow[t]{2}{*}{30} & 30 & sediment & 19839 & -26.1 & 960 & 20 & 797 & 872 & 62.9 \\
\hline & & & & & & & 897 & 928 & 31.9 \\
\hline \multirow[t]{3}{*}{48} & 48 & charcoal & 19840 & -26.8 & 2180 & 20 & 2124 & 2184 & 32.4 \\
\hline & & & & & & & 2193 & 2206 & 2.7 \\
\hline & & & & & & & 2231 & 2306 & 59.9 \\
\hline \multirow[t]{4}{*}{65} & 65 & charcoal & 15487 & -26.4 & 2140 & 25 & 2010 & 2019 & 1.2 \\
\hline & & & & & & & 2040 & 2159 & 76.6 \\
\hline & & & & & & & 2174 & 2175 & 0.2 \\
\hline & & & & & & & 2250 & 2299 & 16.9 \\
\hline \multirow[t]{3}{*}{135} & 135 & charcoal & 19841 & -24.9 & 2420 & 25 & 2354 & 2494 & 79.9 \\
\hline & & & & & & & 2597 & 2611 & 3 \\
\hline & & & & & & & 2638 & 2683 & 12.1 \\
\hline $180-190$ & 185 & charcoal & 15033 & -25.3 & 3090 & 30 & 3227 & 3374 & 95 \\
\hline \multirow[t]{4}{*}{209} & 209 & sediment & 19842 & -25.3 & 4140 & 26 & 4574 & 4729 & 64.7 \\
\hline & & & & & & & 4732 & 4743 & 2.2 \\
\hline & & & & & & & 4747 & 4774 & 9.4 \\
\hline & & & & & & & 4776 & 4820 & 18.7 \\
\hline
\end{tabular}




\begin{tabular}{llllllllll}
$280-290$ & 285 & sediment & 15488 & -24.3 & 7430 & 40 & 8181 & 8343 & 95 \\
$430-440$ & 435 & sediment & 20812 & -25.9 & 11410 & 40 & 13139 & 13332 & 95 \\
\hline
\end{tabular}

Table 2. Radiocarbon dates from the Mulhedoy colluvial stratigraphic section.

\begin{tabular}{|c|c|c|c|c|c|c|c|c|c|}
\hline $\begin{array}{l}\text { Depth } \\
\text { (cm) }\end{array}$ & $\begin{array}{l}\text { Plot } \\
\text { Pt. } \\
\text { (cm) }\end{array}$ & Material & $\begin{array}{c}\text { UGA } \\
\text { Lab \# }\end{array}$ & $\begin{array}{c}\delta^{13} \mathrm{C} \\
\%\end{array}$ & ${ }^{14} \mathrm{C} B P$ & $\begin{array}{c}+/-1 \\
\text { Sigma }\end{array}$ & $\begin{array}{c}95 \% \\
\text { C.I. } \\
\text { Min. } \\
\text { Cal. } \\
\text { BP }\end{array}$ & $\begin{array}{c}95 \% \\
\text { C.I. } \\
\text { Max. } \\
\text { Cal. } \\
\text { BP }\end{array}$ & $\begin{array}{c}\text { Prob } \\
\%\end{array}$ \\
\hline 0 & 0 & surface & n.a. & n.a. & -63 & 1 & -65 & -62 & 95 \\
\hline 33 & 33 & charcoal & 20169 & -24.6 & 840 & 20 & 701 & 786 & 95 \\
\hline \multirow[t]{4}{*}{$55-60$} & 57.5 & charcoal & 20170 & -24.1 & 3560 & 25 & 3728 & 3747 & 3.9 \\
\hline & & & & & & & 3766 & 3792 & 6.2 \\
\hline & & & & & & & 3823 & 3925 & 83.6 \\
\hline & & & & & & & 3950 & 3958 & 1.2 \\
\hline \multirow[t]{2}{*}{$85-90$} & 87.5 & charcoal & 11775 & -26.5 & 3600 & 20 & 3846 & 3933 & 75.1 \\
\hline & & & & & & & 3939 & 3970 & 19.9 \\
\hline \multirow[t]{4}{*}{$110-120$} & 115 & charcoal & 20171 & -25.0 & 3560 & 25 & 3728 & 3747 & 3.9 \\
\hline & & & & & & & 3766 & 3792 & 6.2 \\
\hline & & & & & & & 3823 & 3925 & 83.6 \\
\hline & & & & & & & 3950 & 3958 & 1.2 \\
\hline $120-130$ & 125 & sediment & 20536 & -24.3 & 7060 & 35 & 7831 & 7961 & 95 \\
\hline \multirow[t]{4}{*}{ 150-155 } & 152.5 & sediment & 15489 & -24.4 & 8980 & 30 & 9941 & 9989 & 8.7 \\
\hline & & & & & & & 10014 & 10022 & 0.7 \\
\hline & & & & & & & 10040 & 10059 & 2.6 \\
\hline & & & & & & & 10142 & 10230 & 82.9 \\
\hline $180-182$ & 181 & sediment & 15034 & -23.4 & 14850 & 40 & 17894 & 18218 & 95 \\
\hline
\end{tabular}



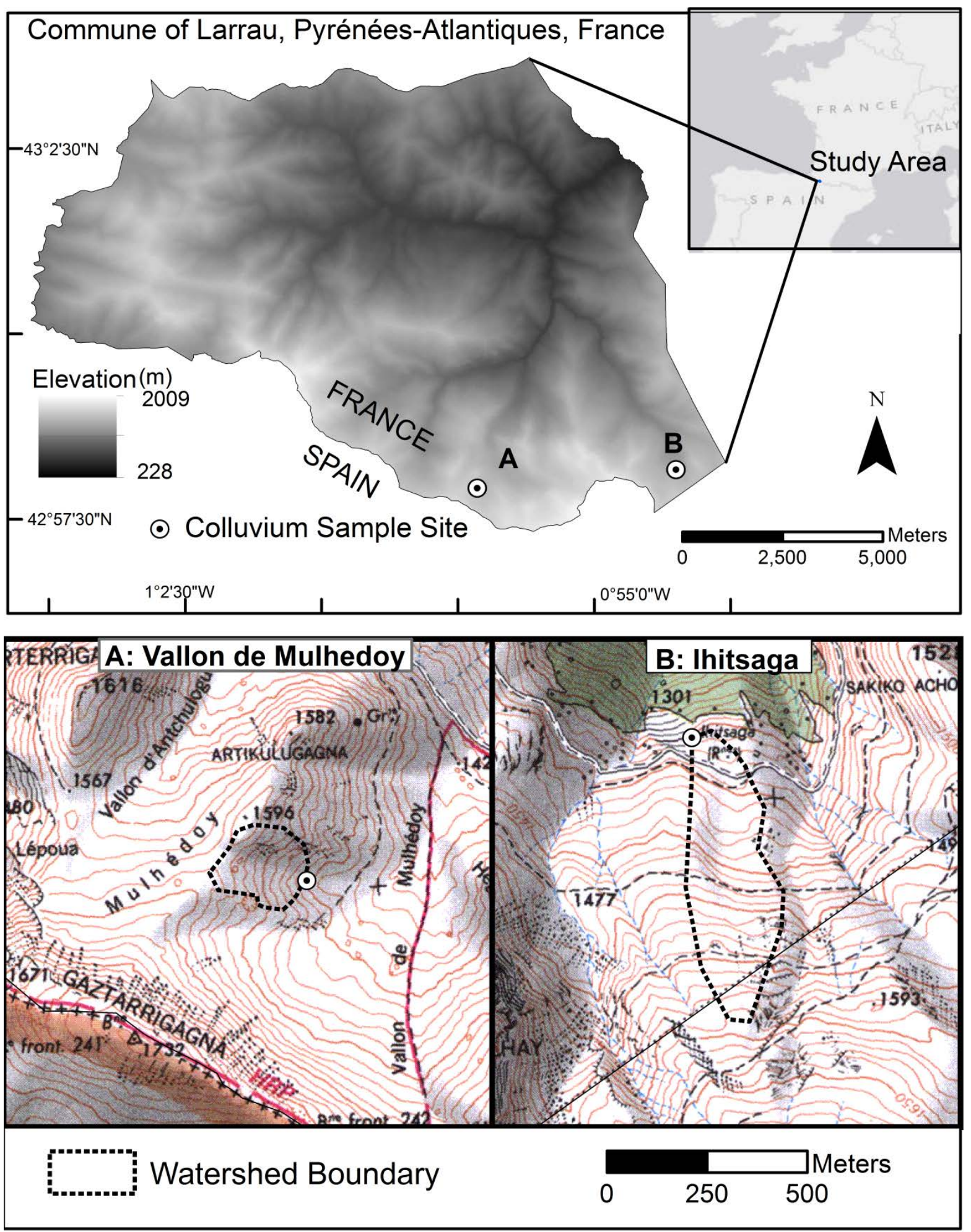

Fig. 1 


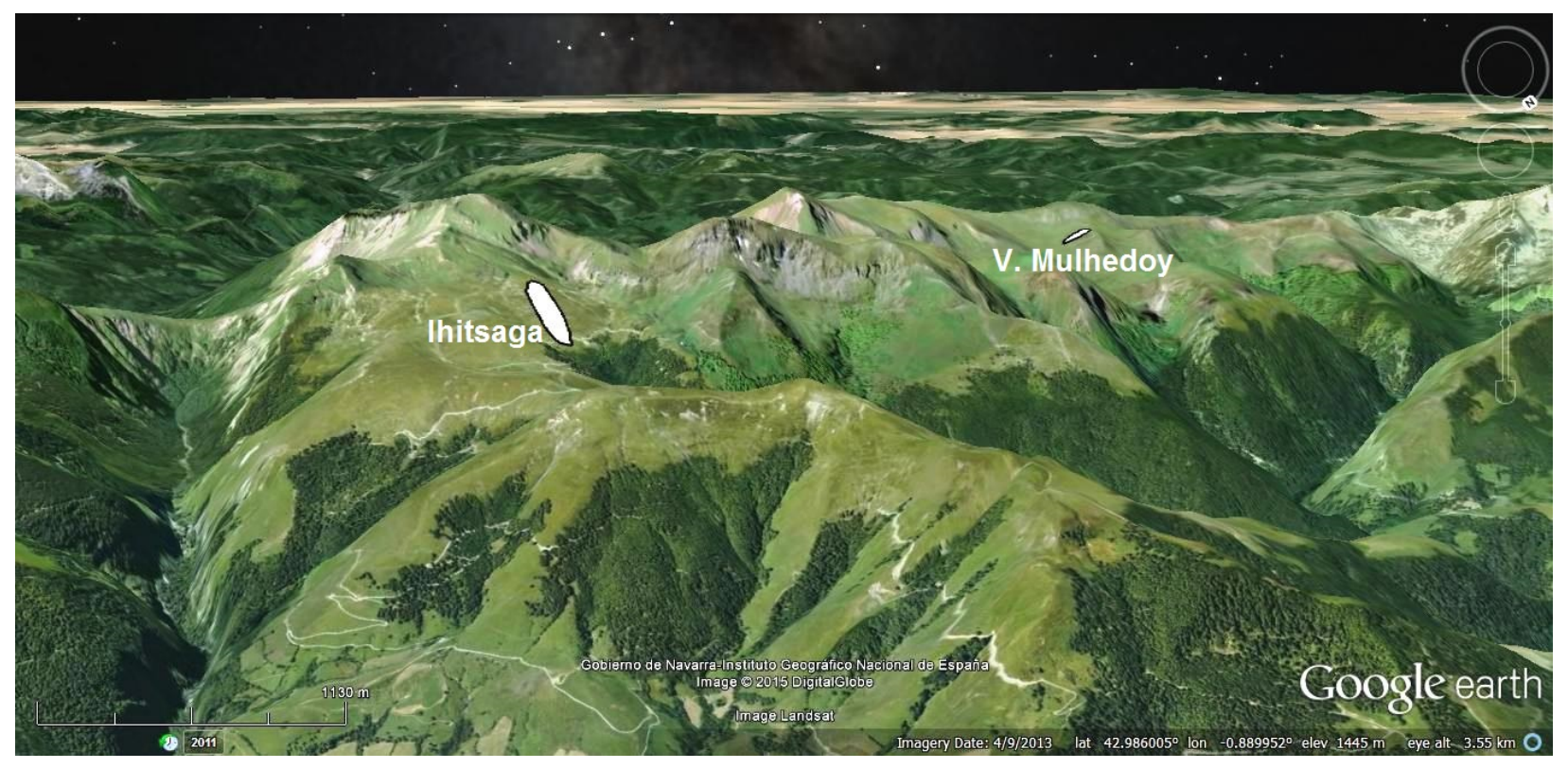

Fig. 2 
Fig. 3

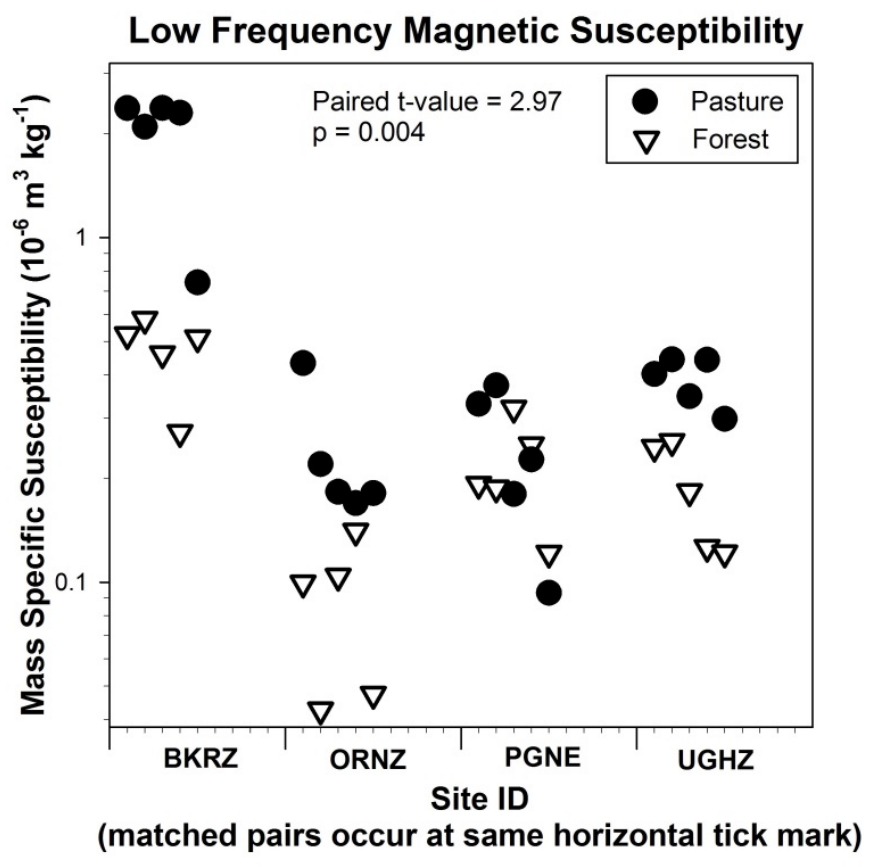




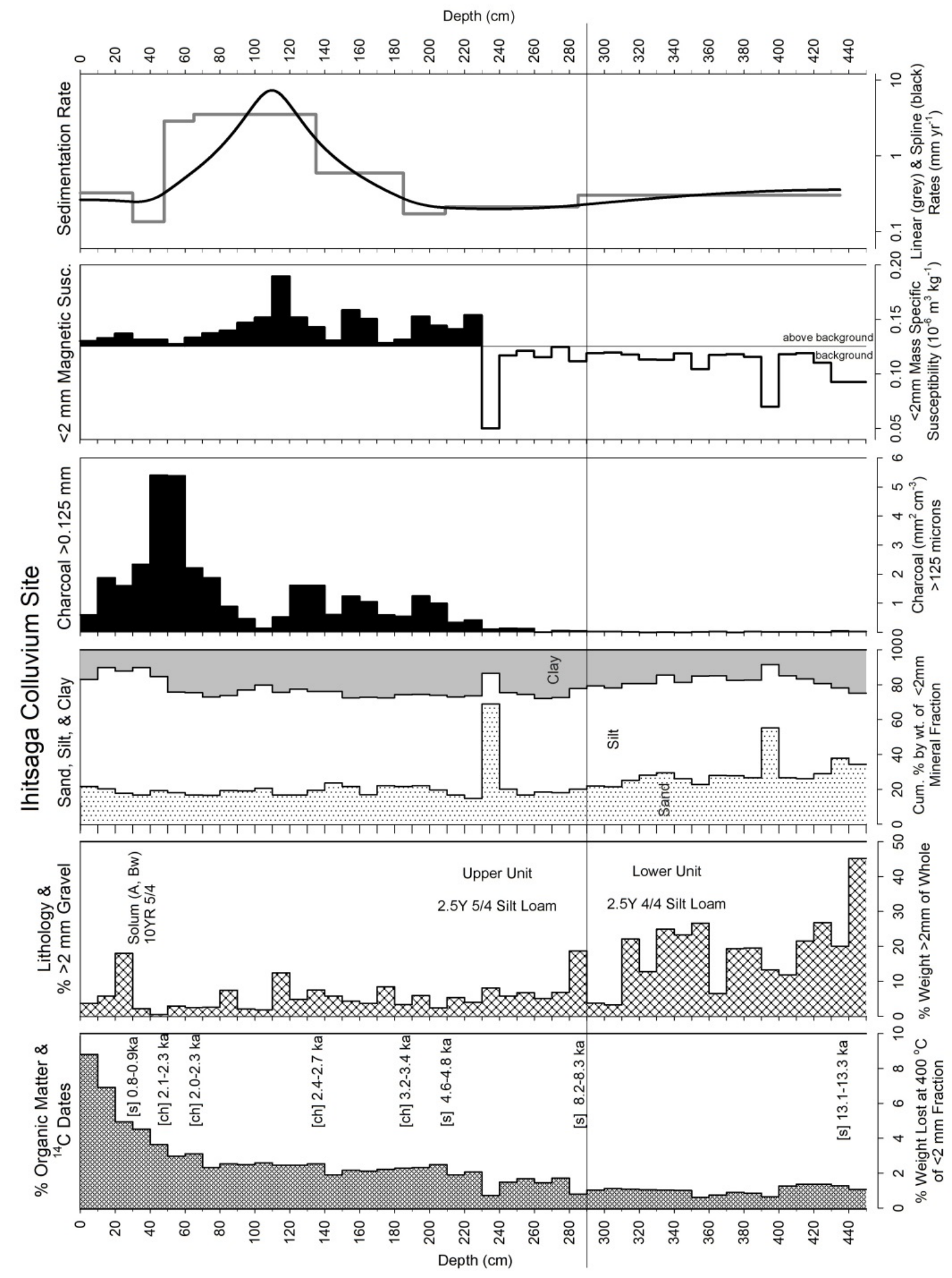

Fig. 4 
Fig. 5

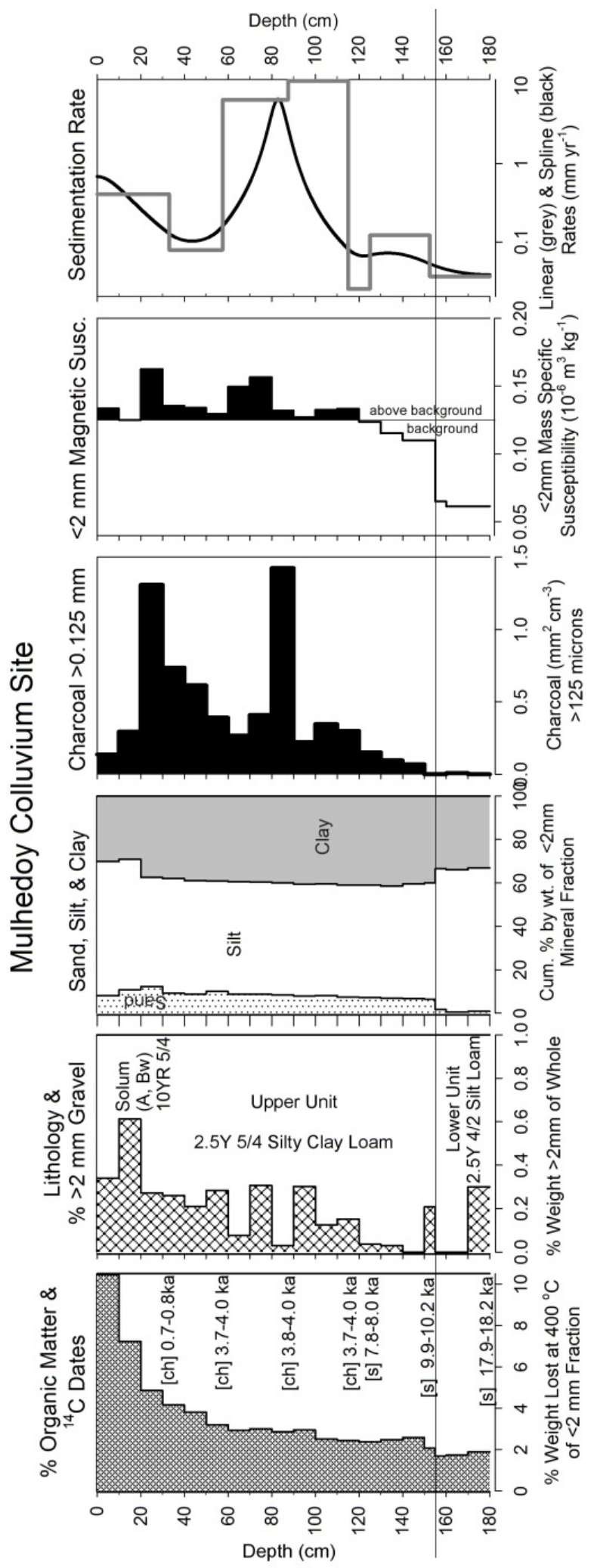


Fig. 6

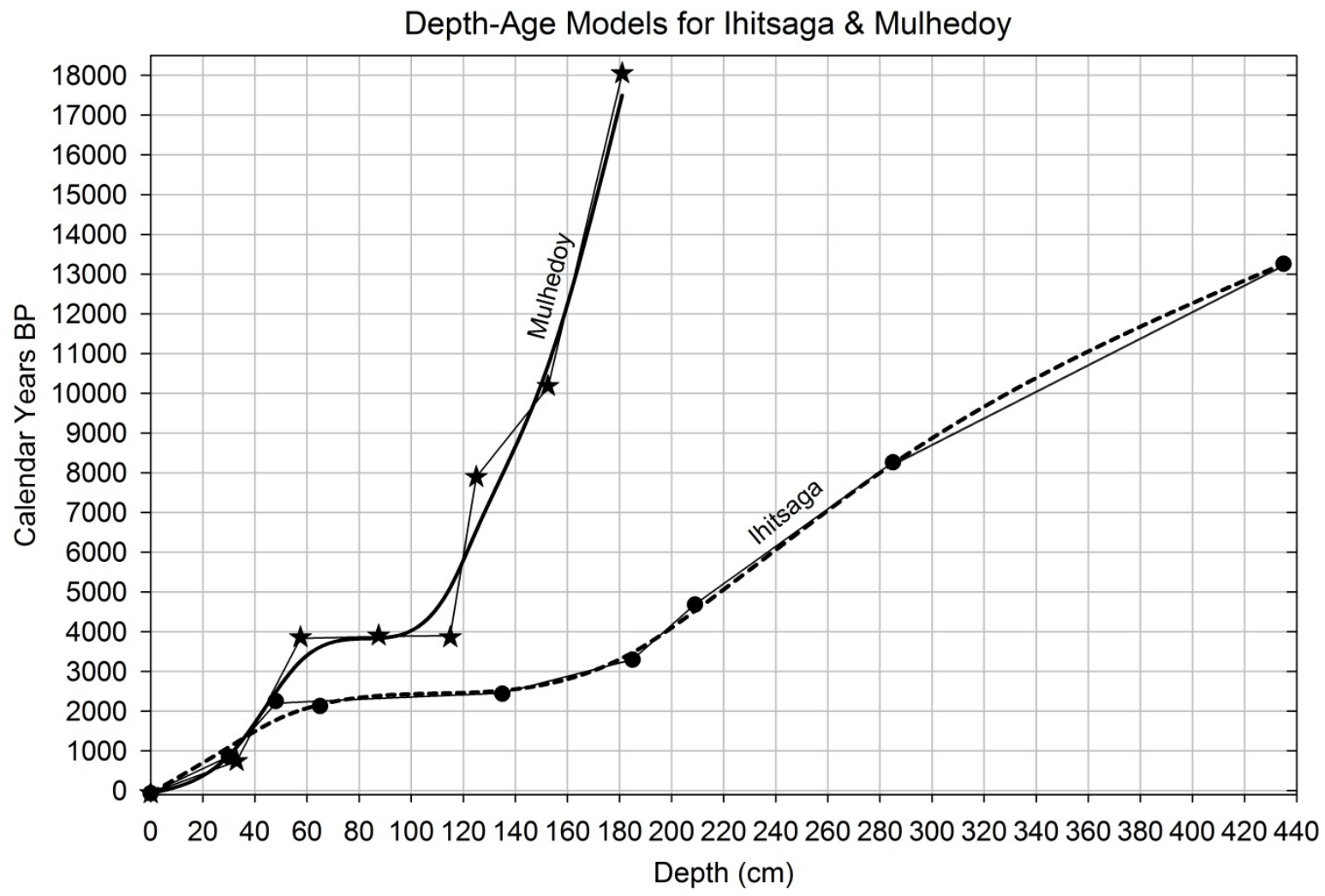




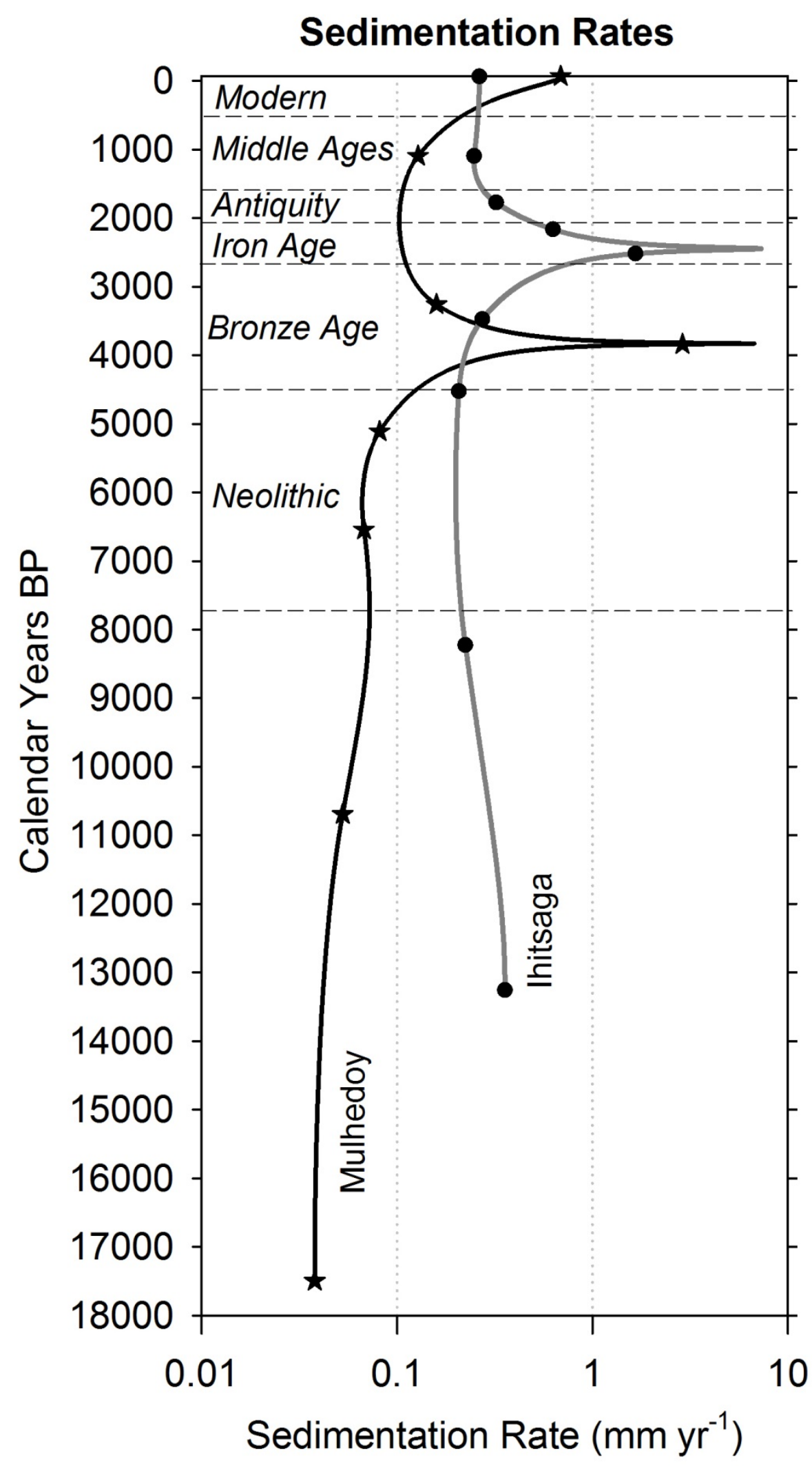

Fig. 7 
Fig. 8
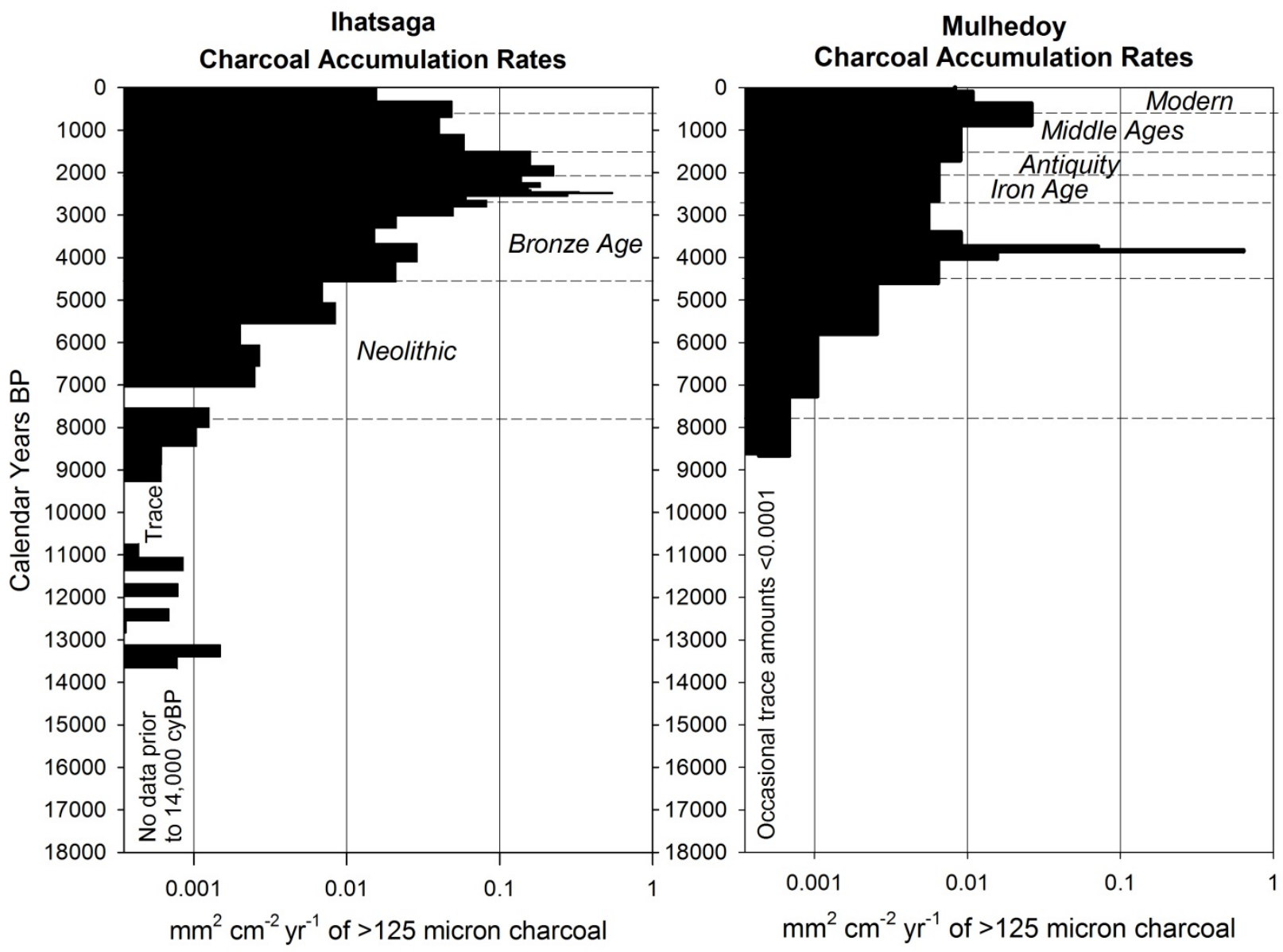